\title{
Editorial
}

\section{MEDICAL EDUCATION: COVID JOURNEY}

\section{Puranam Vatsalaswamy}

\author{
Dr.D. Y. Patil Medical College, Hospital and Research Center, Pune, Maharashatra, India
}

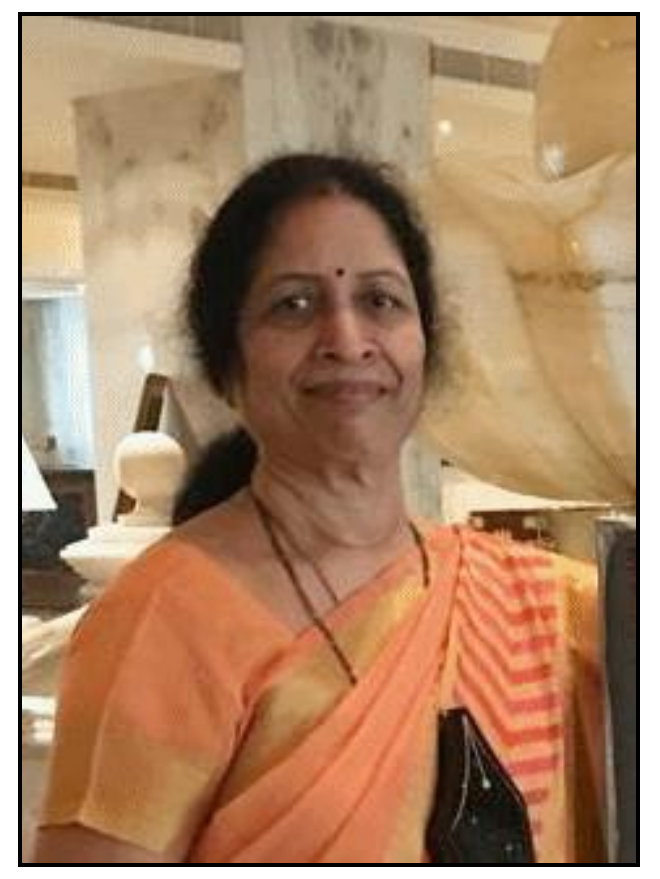

We all were caught unawares and were in for a rude shock! In fact we were forced by a tiny miniscule RNA with a spiked cover to take a virtual journey in situ to all the countries all over the globe. Harsh reality it is! The COVID - 19 pandemic hit all of us very badly in all the fronts leaving us temporarily paralyzed especially in our daily lives, economies and Educational Institutions.

The teachers, students and the educational institutions had to face an academic stand still and that forced us to introspect and then see the challenges to be faced and the outcome. We are not free of COVID and it is still haunting us with hopes of a successful vaccine showing up sooner or later at our doorstep!
While it is crucial to contain COVID - 19 spread, it is also important to continue educational process making use of technology. We had to have a transition from conventional /traditional teaching to an online mode of teaching which became imperative (Rajab et al., 2020). We had to find ways to deal with the academic stress and had to give a sense of direction and credibility to reorient and restructure the curriculum and tried all modes of communication. We wanted to make sure that students are engaged in effective and constructive ways. This paradigm shift allowed students to participate actively. We needed to take measures to safeguard the interests of teaching fraternity as well as the students.

Faculty tried many Virtual platforms for teaching such as Google classroom, ZOOM, Cisco Webex, Microsoft Teams etc. Conducting clinics and practicals posed a challenge and lot of innovative ideas emerged. Evaluation and Assessment online of both theory and practicals had to be done due to the pandemic and the methods needed to be foolproof to avoid unethical practices. Extraordinary situations needed flexible solutions in terms of assignments, academic schedules and examinations (Sahni, 2020; Stiickelberger, 2020; Winthrop, 2020). It has become our moral responsibility, lot of lessons were learnt while sharing experiences with colleagues and most important was addressing anxiety and stress of students and parents.

We were underprepared initially with surge of infections that led to moral distress with issues of lockdown of travel, work, social and education activities. Regarding safe disposable of bodies, standard protocol had to be followed such as hand hygiene, use of body bag, protective gear of mask, disposable gown and eye protection. Sentiments of family to be honored and dignity of 
dead have to be maintained. Strict guidelines had to be followed regarding disposal of waste.

Educational Integrity became vulnerable, moral trauma due to unpreparedness, compromised clinical exposure- Bedside clinics, Ward rounds and medical health issues due to academic stress. Public Health measures to be strengthened with safety measures such as social distancing, use of sanitizer and wearing a mask. Stress management is very essential and is the need of hour.

The extreme economic strain caused by the pandemic will also lead to serious financial challenges for students and higher educational institutions. Work from home, self-isolation and online communication are difficult experiences and will become tougher in the near future. To overcome the lack of one to one physical interaction between medical students and patients 'blended learning' could be a relevant option in today's scenario (O'Byrne et al.,; 2020). Character building and self-reliance are important part of academic education too. One should be able to be balanced/ buoyant in adverse circumstances, should develop moral resilience an ability to manage the anxiety and stress amongst the stake holders. Training of medical students and faculty and public health awareness for dealing with an unexpected pandemic like the present Corona outbreak is essential.

To conclude, we need to remember and note down the lessons learnt and be better prepared for the eventuality in future if it happens again. The take home message for all is think positive, stay safe and stay healthy.

\section{REFERENCES}

O'Byrne L et al. 2020. Medical Students and COVID-19: the need for pandemic preparedness. .J.Med Ethics. 46: 623-26. Available from: doi:10.1136/medethics-2020106353.

Rajab M H et al. 2020. Challenges to online Medical education during the covid-19 Pandemic. Cureus. Available from: doi : 10.7759/cureus.8966

Sahni U. 2020. Covid-19 in India: Education disrupted and lessons learned. BROOKINGS. Education Plus Development. Available from: https://www.brooking.edu/blog/education-plusdevelopment/2020/05/14/covid-19 in- Indiaeducation- disrupted- and- lessons-learned

Stiickelberger C. 2020. Covid-19 and the ethical responsibility of universities, university World News. Global. Available from: https://www.universityworldnews.com/post.php? story $=20200410080845845$.

Winthrop R. 2020 Top-10 risks and opportunities for education in the face of COVID-19. Brookings Education Plus Development. Available from: https://www.brookings.edu/ blog/education-plus development/2020/04/10/ top-10-risks-and-opportunities-for-education-inthe-face-of-covid-19. 